Syntax Literate: Jurnal Ilmiah Indonesia p-ISSN: 2541-0849

e-ISSN: 2548-1398

Vol. 7, No. 1, Januari 2022

\title{
PROBLEMATIKA SHOLAT JUMAT SELAMA PANDEMI COVID 19
}

\author{
Siti Muhayati, Diana Ariswanti Triningtyas, Carlos Lazaro Prawirosastro \\ Universitas PGRI Madiun, Jawa Timur, Indonesia \\ Email: sitimuhayati@unipma.ac.id,dianaariswanti@unipma.ac.id, \\ carlos.prawirosastro@hangtuah.ac.id
}

\begin{abstract}
Abstrak
Tujuan penelitian ini adalah untuk mengetahui problematika sholat jumat yang muncul selama pandemi covid 19. Salah satu aspek kehidupan yang diatur oleh Islam adalah sosial. Sosial adalah segala yang lahir, tumbuh dan berkembang dalam kehidupan masyarakat. Segala sesuatu yang lahir dari kehidupan social berupa peraturan, dimana peraturan tersebut terkait dengan interaksi atau kontak social atau komunikasi social. Peraturan tersebut mengandung nilai keadilan, persamaan hak, kemerdekaan, simpati, solidalitas, empati dan simpati, dan Islam memberi nilai pada semua peraturan tersebut. Salah satu interaksi soaial berupa hubungan manusia dengan dengan manusia selain dengan Allah dan alam. Hubungan manusia dengan manusia antara lain silaturrahim. Wadah silaturrahim adalah jamaah sholat jumat. Di masa pandemi covid 19 menimbulkan problematika dalam penyelenggarakan shalat jumat. Jenis penelitian ini adalah penelitian literer dengan metode kualitatif deskripsi yaitu dengan menyajikan data yang diperoleh dari sumbernya. Sumber data yang digunakan adalah artikel ilmiah di jurnal baik jurnal yang terindek google scholar, sinta, bulletin Islam, majalah Islam, buku tentang Islam. Analisa datanya dengan deskripsi yaitu menyajikan data yang telah dipilih yang sesuai dengan judul, lalu dibahas selanjutnya ditarik kesimpulan. Hasil penelitian menunjukan bahwa di masa pandemic covid 19 menimbulkan problemamatika baik jika menyelenggarakan shalat jumat maupun tidak menyelenggarakan shalat jumat.
\end{abstract}

Kata Kunci: problematika; sholat jum'at; pandemi covid 19

\section{Abstract}

The purpose of this study was to find out the problems of Friday prayers that arose during the covid 19 pandemic. One aspect of life regulated by Islam is social. Social is everything that is born, grows and develops in people's lives. Everything that is born from social life is in the form of regulations, where these regulations are related to social interaction or contact or social communication. These regulations contain values of justice, equality of rights, independence, sympathy, solidity, empathy and sympathy, and Islam places value on all these regulations. One of the social interactions is in the form of human relationships with humans other than with God and nature. Human relations with humans, among others, silaturrahim. The forum for friendship is the congregation for Friday prayers. During the COVID-19 pandemic, it caused problems in organizing Friday prayers.

$\begin{array}{ll}\text { How to cite: } & \text { Muhayati, S. et. al (2022) Problimatika Sholat Jumat Selama Pandemi Covid 19. Syntax Literate: Jurnal } \\ & \text { Ilmiah Indonesia, 7(1). http://dx.doi.org/10.36418/ Syntax-Literate.v7i1.6064 } \\ & \\ \text { E-ISSN: } & \text { 2548-1398 } \\ \text { Published by: } & \text { Ridwan Institute }\end{array}$


This type of research is a literary research with a descriptive qualitative method, namely by presenting data obtained from the source. The data sources used are scientific articles in journals indexed by Google Scholar, Sinta, Islamic bulletins, Islamic magazines, books about Islam. Analysis of the data with a description, namely presenting data that has been selected according to the title, then discussed and then drawn conclusions. The results of the study showed that during the COVID-19 pandemic, it caused problems whether holding Friday prayers or not holding Friday prayers.

Keywords: problematika; friday prayer; covid 19 pandemic

Received: 2021-12-20; Accepted: 2022-01-05; Published: 2022-01-15

\section{Pendahuluan}

Problematika adalah masalah yang timbul karena adanya kesenjangan antara konsep atau teori dengan pelaksanan atau antara harapan dan realita. Menurut (Efendi, Lubis, \& Nasution, 2018) problematika adalah masalah yang belum bisa terpecahkan karena ada kendala (Efendi et al., 2018). Penulis lain berpendapat bahwa problematika adalah masalah yang mengganggu, menghambat, mempersulit terselenggaranya suatu program (Hikmah, 2019). Sedang menurut (Wahyuningsih, 2021), Problematika adalah masalah yang menghambat proses suatu program. Dari beberapa pendapat tentang pengertian problematika adalah masalah yang disebabkan kesenjangan antara peraturan dengan pelaksanaan.

Salah satu aspek kehidupan yang diatur oleh Islam adalah social. Sosial adalah segala yang lahir, tumbuh dan berkembang dalam kehidupan masyarakat. Segala sesuatu yang lahir dari kehidupan social berupa peraturan, dimana peraturan tersebut terkait dengan interaksi atau kontak atau komunikasi social (Prawiro, 2019). Peraturan tersebut mengandung nilai 1 . Keadilan yaitu menempatkan sesuatu pada tempatnya (Widyakso Rendra, 2021). Persamaan hak yaitu semua manusia dihadapan hukum atau Allah memiliki hak dan kewajiban yang sama (Amalia Resti, 2015). Kemerdekaan yaitu manusia berhak merdeka dalam memiliki ruh, memiliki akal sehat, berpendapat, memilih, belajar (Humas Paser, 2019). Simpati adalah keikutsertaan merasakan perasaan orang lain dan memberikan solusi (Mardatila Ani, 2021b). Solidalitas adalah saling percaya antara anggota yang satu dengan yang lainnya dalam satu kelompok (Dosen Pendidikan 3, 2021). Empati adalah merasakan perasaan orang lain dengan memberikan (Mardatila Ani, 2021b). Islam memberi nilai pada semua peraturan yang lahir dari kehidupan soial tersebut. Dalam Islam interaksi soaial berupa hubungan manusia dengan Allah (dipersonafikasikan karena Allah Ghaib), hubungan manusia dengan manusia, hubungan manusia dengan alam. Hubungan manusia dengan manusia antara lain silaturrahim. Silaturahim yaitu interaksi, kontak atau interaksi social, dan komunikasi. Salah satu wadah silaturrahim adalah jamaah sholat jumat. Di masa pandemik covid 19, muncul problematika penyelenggaran sholat jumat yaitu di selenggarakan atau tidak diselenggarakan. Jika diselenggarakan shalat jumat maka 
muncul klaster baru penularan covid 9, karena shalat jumat dilaksanakan secara jamaah dimana minimal jamaahnya berjumlah empat puluh orang. Jika tidak diselenggarakan muncul beberapa problem terkait dengan hukum shalat jumat.

Sholat Jumat adalah sholat yang terdiri dari dua rokaat yang didahului dengan dua khuthbah yang dilaksanakan di waktu sholat dhuhur (Alsha Tour, 2017). Sholat Jum'at ini wajib bagi muslim baligh, tidak wajib bagi muslimah kanak kanak maupun baligh, anak anak, nenek dan kakek yang sudah tua renta. Orang orang yang dikecualikan ini dari kewajiban sholat jumat, mereka mengganti dengan shalat dhuhur. Muslim baligh yang tidak melaksanakan sholat tiga kali berturut turut dikategorikan orang fasiq. Muslim baligh boleh tidak melaksanakan sholat satu kali atau dua kali apabila muslim dalam keadaan pergi sejauh dia boleh shoalt jama' qashar, atau muslim baligh tersebut dalam keadaan sakit sehingga tidak mampu melaksanakan sholat jumat (Alsha Tour, 2017).

Hikmah sholat jumat ditinjau dari segi aqidah yaitu menambah ilmu Islam yang berimplikasi memperkut iman dan taqwa muslim pada Allah dan peraturanNya (Alsha Tour, 2017). Ditinjau dari segi social maka akan mempererat ukhuwah Islamiyah, ukhuwah wathaniyah, dan ukhuwah insaniyah karena terjadi interaksi atau kontak social, komunikasi, sehingga diantara mereka mengetahui kondisi dan situasi para anggota jamaah sholat jum'at apakah salah satu anggota atau beberapa orang dalam keadaan sehat atau tidak dan dalm keadaan kesulitan ekonomi atau tidak (Koesno, 2020). Dengan demikian akan memunculkkan solidaritas, simpti dan empati. Ditinjau dari segi ekonomi maka para anggota jamaah sholat jumat mampu untuk mengadakan simpan pinjam tanpa bunga agar anggota jamaah tersebut tidak terbelenggu dengan rentener yang mengikatnya (Azizah Kurnia, 2021). Ditinjau dari segi pendidikan, sholat jum'at mendidik anak anak untuk bersosialisasi dengan orang lain, membentuk jiwa kepemimpian karena jika ada sekelompok orang pasti ada pemimpinnya (Indera, 2020).

Urutan tatacara sholat jumat adalah sebagai berikut 1. Adzan pertama kali, tanda pemanggilan para jamaah sholat jumat, 2. Adzan kedua, dilakukan sebagai tanda dimulainya khotbah jumat, 3. Khotbah jumat, 4. Iqomah, 5. Sholat jumat (Azizah Kurnia, 2021).

Shaf jamaah sholat jumat sama dengan shaf jamaah lima sholat wajib lainnya yaitu diperintahkan untuk luruskan shaf shaf, dan merapatkan shaf sehingga tidak ada celah celah diantara orang sholat sebagaimana Sabda Nabi Muhammad Shallallahu'alaihi Wassalam yang artinya: luruskan shaf kalian dan hendaklah kalian saling menempel, karena aku melihat kalian dari balik punggungku. H.R. Bukhari no 719 dan Sabdanya yang lain yang artinya: luruskan shaf shaf kalian, karena lurusnya shaf adalah kesempurnaan shalat. HR Muslim no.433 (Purnama, Yulian, 2021). Hikmah dalam meluruskan shaf adalah terikatnya hati orang orang yang sholat dan terhidar dari berselisihnya hati. Sebagaiman Sabda Nabi Muhammad Shalallaho'alaihi Wassalam yang artinya dari Abu Mas'ud radhiallahu'anhu, ia berkata: dahulu Rasulullah Shalallahu'alaihi Wassalam memegang pundak pundak kami sebelum shalat, dan beliaubersabda: luruskan shaf dan jangan bengkok, sehingga hati hati, kalian akan 
bengkok (berselisih) pula. Adapun ancaman bagi yang tidak meluruskan shaf adalah dalam sholat berdosa karena perintah meluruskan shaf adalah wajib (Purnama, Yulian, 2021). Demikian diperintahkan untuk merapatkan shaf sebagaimana Sabda Nabi Shalallahu'alaihi Wassalam yang artinya Dari Anasbin Malik: Setiap orang dari kami merapatkan pundak kami dengan pundak sebelahnya, dan merapatkan kaki kami dengan kaki sebelhnya. HR, Al Bukharino (Purnama, Yulian, 2021). Ancaman bagi orang yang tidak mau merapatkan shaf dalam shalatnya maka orang tersebut menanggung dosa (Purnama, Yulian, 2021).

Pandemi covid 19 telah menebar di Negara Kesatuan Republik Indonesi selama hampir dua tahun. Bahaya dari pabndemi covid 19 adalah 1. Covid 9 ini penularannya sangat cepat dan dapat ditularkan melalui orang perorang melalui media bendadan lingkungn disekitar orang yang memiliki riwyat covid 19, 2. Coroanvirus dapat menyebabkan infeksi pada saluran pernafasan yang umumnya ringan, seperti pilek, tapi covid ini bisa menimbulkan kematian. Dampaknya meluas dalam segala aspek kehidupan manusia baik di bidang ideologi, politik, ekonomi, social, budaya, pertahanan dan keamanan. Demikian juga terdampak pada peraturan Islam tentang perintah wajib shalat jumat di hari jumat. Shalat jumat dilaksanakan dengan berjamaah karena sholat jumat diikuti minimal 40 orang. Rata rata ukuran masjid menampung 40 orang (Rahasanta, 2017) dan dilaksanakan sholat jumat wajib meluruskan dan merapatkan shaf shaf. Cara merapatkan shaf dengan pundak ketemu pundak satu sama lain jamaah sholat jumat. Selain pundak ketemu pundak kaki juga wajib ketemu kaki satu jamaah sholat jumat dengan jamaah lainnya. Covid 19 juga berdampak pada bidang social, ekonomi dan pendidikan yang diselenggarakan di masjid.

Artikel ini kebaruannya terletak pada problematikan sholat jum'at di masa pandemic covid 19. Dalam artikel ini membahas tentang problematika shalat jumat di masa pandemic covi 19 baik problem yang muncul jika shalat jumat diselanggarakan di masa pandemic dan problem yang muncul jika shalat jumat tidak diselenggarakan. Di beberapa artikel tentang problematika sholat jumat di masa pandemic belum ada yang membahasnya, sedangkan artikel dengan judul Meninggalkan Shalat Jumat Hingga 3 Kali Beruntun Saat Covid 19, Ini Hukumnya (Mardatila Ani, 2021). Artikel ini hanya membahas tentang hukum meninggalkan sholat jumat 3 kali beruntun. Artikel lain yang berjudul Isi Lengkap Fatwa MUI tentang Sholat Jumat Saat Pandemi Covid-19 (Firdaus, 2020). Penulis ini memaparkan fatwa MUI tentang sholat jumat saat pandemic covid 19. Penulis lain menyusun artikel dengan judul Hukum Ganti Sholat Jumat dengan Sholat Dhuhur Selama Pandemi Covid 19 (Aditya, 2021). Penulis artikel ini membahas tentang hukum sholat jumat diganti dengan sholat dhuhur selama pandemic.

Tujuan penelitian ini untuk mengetahui problematika sholat jumat yang timbul pada masa pandemic covid 19, dan untuk mengetahui solusi problematika shalat jumat pada masa pandemi covid 19, serta mengetahui problematika shalat jumat di masa pandemic ada solusinya atau tidak baik menyelenggarakan shalat jumat atau tidak, jika ada, solusi tersebut berlaku sampai pandemic covid 19 berakir atau tidak 
Manfaat dari penelitian ini adalah untuk mengetahui problem yang muncul jika shalat jumat diselenggarakan atau tidak diselenggarakan, mengetahui solusi dari problem shalat jumat baik diselenggarakan atau tidak diselenggarakan, mengetahui berlaku solusi dari problem shalat jumat baik diselenggarakan atau tidak diselenggarakan, menambah wawasan bahwa silaturrahim ini tetap terjaga walau tidak bisa sholat jumat dan tidak bertemu satu sama lain dalam tiap minggunya, namun masih mengurangi rasa kebersamaan; mengetahui hukum tidak melaksanakan sholat jumat sebanyak tiga kali beruntun; cara sholat jumat di masa pandemi covid 19.

\section{Metode Penelitian}

Jenis penelitian ini adalah penelitian literatur dengan metode kualitatif deskripsi yaitu dengan menyajikan data yang diperoleh dari sumbernya (Sugiyono, 2017). Sumber data yang digunakan adalah artikel ilmiah di jurnal baik jurnal yang terindek google scholar, sinta, bulletin Islam, majalah Islam, buku tentang Islam. Analisa datanya dengan deskripsi yaitu menyajikan data yang telah dipilih yang sesuai dengan judul, lalu dibahas selanjutnya ditarik kesimpulan.

\section{Hasil dan Pembahasan}

\section{A. Hasil Penelitian}

Sholat jumat di masa pandemi covid 19. Dua tahun Negara Kesatuan Republik Indonesia sudah dalam masa pandemic covid 19, dilanjutkan dengan mutasi covid 19 jenis delta, sehingga menimbulkan beberapa problem baik jika diselenggarakan sholat jumat atau tidak diselenggarakannya di masa pandemic covid 19. Ada beberapa problem ditemuka 1. Jika shalat jumat diselenggarakan di masa pandemi covid 19 yaitu a. Hukum memakai masker dalam shalat jumat, b. Hukum tidak meluruskan shaf dalam shalat jumat, c. Hukum tidak merapatkan shaf dalam shalat jumat, d. Hukum penyelenggaraan berbilang atau dengan cara sif dalam sholat jumat disebabkan masjid tidak bisa menampung jamaah shalat jumat yang seharusnya, e. Hukum penyelenggaraan shalat jumat di mushala atau di rumah, f. Hukum memperpendek khutbah jumat, g. Hukum memperpendek sholat dengan cara memilih surat pendek dari Al Qur'an. 2. Jika shalat jumat tidak diselengarakan. Beberapa probem jika shalat jumat tidak diselenggrakan yaitu a. Di bidang Aqidah, b. Di bidang Hukum Sholat Jumat, c. Di bidang Sosial, d. Di bidang Budaya, e. Di bidang Ekonomi, f. P Di bidang endidikan

\section{B. Pembahasan}

Problem yang muncul di bidang aqidah jika shalat jumat tidak diselenggarakan adalah akan berkurangnya pada iman dan taqwa pada Allah dan peraturanNya khususnya iman dan taqwa pada peraturan Allah terkait sholat jumat, karena salah satu keutamaan jamaah sholat jumat adalah untuk meningkatkan iman dan takwa pada Allah dan peraturan Nya karena ketika dimulai khutbah para khatib menyeru jamaah sholat jumat untuk beriman dan taqwa pada Allah dengan sebenarnya taqwa dan hendaklah mati dalam keadaan Islam sebagaimana firman Allah artinya: Hai 
orang orang yang beriman, bertawalah kepada Allah sebenar benar takwa kepada Nya. Dan janganlah kamu mati kecuali kamu dalam keadaan muslim (Q.S. Ali Imran ayat 102).

Selain itu muncul perbedaan pendapat mengenai terselenggaranya shalat jumat atau tidak di masa pandemi covid 19. Menurut Majlis Ulama Indonesia yang selanjutnya disingkat MUI melalui fatwanya yang tertuang dalam Fatwa MUI Nomor 14 tahun 2020, mengenai larangan menyelenggarakan sholat jumat di wilayah yang sedang mengalami pandemic covid 19 , dalam rangka memutus rantai penularan covid 19 dengan cara tidak bertemu tatap muka, hal ini rekomendasi dari ahli medis (Al Husna, Hana Isnaini). Sedangkan masyarakat kontra terhadap fatwa MUI karena mengimani bahwa sholat jumat wajib dan jika tidak melaksanakan 3 kali beruntun maka mereka termasuk orang fasiq. Kata Al Husna, Hana Isnaini, masyarakat yang berpendapat seperti ini perlu diedukasi dengan cara diberi hikmah bahwa. 1. covid 9 ini penularannya sagat cepat dan dapat ditularkan melalui orang perorang melalui media benda dan lingkungn disekitar orang yang memiliki riwayat covid 19, 2. Coroana virus dapat menyebabkan infeksi pada saluran pernafasan yang umumnya ringan, seperti pilek, tapi covid ini bisa menimbulkan kematian, 3. Nabi Muhammad sendiri juga menghindari tempat dimana sedang terjangkit wabah sebagaiman Hadits Nabi Muhammad SAW dari Saad bahwa Nabi Muhammad saw bersabda yang artinya : Jika Kamu mendengar wabah di suatu wilayah, maka janganlah kamu memasukinya, Tapi jika terjadi wadah di tempat kamu berada, maka jangan tinggalkan tempat itu (Al Husna, Hana Isnaini).

Problem aqidah lainnnya adalah penanaman iman dan takwa pada Allah dan peraturan Nya terhadap anak anak laki laki yang belum baligh yang terkait kewajiban shalat jumat di masjid. Tidak terselenggaranya sholat jumat maka anak tidak dapat merasakan pengalaman sholat jumat yang diselenggarakan tiap hari jumat seminggu sekali (Anggraeni, 2017).

Problim lainya jika tidak terselengananya sholat jumat dalam bidang hukum sholat jumat. Sholat jumat wajib dilaksanakan oleh muslim baligh tiap hari jumat, kecuali ada halangan syar'i hanya dibolehkan tidak sholat jumat maksimal tiga kali terus menerus. Problim sholat jumat di masa pandemic Covid 19 ini adalah sholat jumat kejelasan hukum tidak melaksanakan sholat jumat selama pandemi covid 19. Selama pandemi sholat jumat tidak diselenggarkan beberapa kali dan lebih dari tiga kali beruntun sehingga muslim tidak melaksanakan kewajiban sholat jumat. Oleh karena itu muslim termasuk orang fasiq atau tidak karena tidak sholat jumat sebanyak tiga kali beruntun. Hukum tidak shalat sebanyak tiga kali beruntun masih menjadi problem karena ini hukumnya tidak bisa dirubah kecuali jika hambatan melaksanakan sholat jumat hilang maka hukum sholat kembali pada hukum semua yaitu hukum shalat jumat wajib 'ain. Problim hukum sholat tidak dilaksanakan tiga kali beruntun menurut Majlis Ulama Indonesia didasarkan hasil ijtihad maka memberi fatwa bahwa hukum tidak melaksanakan shalat jumat tiga kali berurutan karena ada halangan syar'i adalah dihukum mubah dasar hukumnya adalah adalah 
orng yang meyakini bahwa shalat jumat salah satu kewajiban dan tidak dapat melaksanakan terhalang oleh syar'i maka dibolehkan. Halangan syar'i ada dua yaitu pertama jika orang tersebut sakit dan durasi sakitnya sampai tidak bida melaksanakan sholat jumat tiga kali berturutan dan yang kedua adalah halangan syar'i yang berupa kekuatiran terjadinya sakit karena dalam kondisi berkumpul dan berkerumun itu diduga kuat akan terkena wabah atau menularkan penyakit, maka ini menjadi uzurdalam shalat jumat (Asrorun Niam Seketaris Jendral MUI dalam Detik .com, 2020). Jo Beni berpendapat bahwa hukum tidak melaksanakan sholat jumat tiga kali berurutan adalah dibolehkan jika orang sehat dan belum terpapar covid 19 ada dalam kawasan yang potensi penularannya tinggiatau sangat tinggiberdasarkan ketetapanpihak yang berwenang, maka boleh meninggalkan sholat jumat dan mengganti sholat dhuhur (Jo Beni, 2020). Jadi solusi dari problem ini berlaku selama pandemic covid 19, jika sudah hilang maka tidak melaksanakan sholat jumat tiga kali berurutan kembali ke hukum semula yaitu haram atau berdosa.

Problim sholat jumat yang lain di masa pandemic 19 adalah tentang shaf dalam sholat jamaah. Melurusan shaf merupakan salah satu kewajiban yang dilaksanakan dalam sholat jamaah, pada masa pandemi covid 19 dengan peraturauran dari pemerintah wajib menjaga jarak minimal 1 meter maka untuk meluruskan shaf mendapatkan kesulitan walau sudah ada garis pembatas masih kelihatan tidak lurus. Jamaah yang tidak meluruskan shafnya mendapat sanksi dosa, tidak mempererat hati hati para jamaah satu sama lain dan memberi peluang perselisihan (Purnama, Yulian, 2021) Sholat dalam jamaah selain mempunyai kewajiban meluruskan shaf dalam sholat jamaah juga mempunyai kewajiban untuk mempererat shafnya dengan cara menempelkan bahu seorang jamaah kepada jamaah lain, dan menempelkan mata kaki seorang jamaah dengan mata kaki jemaah lain, sedang pemerintah mewajibkan jamaah satu dengan jamaah lain menjaga jarak meter, hal ini sulit dilakukan oleh jamaah karena jika tidak mempererat shafnya mendapat sanksi berupa dosa, tidak mempererat hati hati jamaah satu sama lainnya dan memberi peluang untuk terjadi perselisihan (Purnama, Yulian, 2021). Dalam hal ini At Tusi Buchari berpendapat bahwa menjaga jarak dalam sholat jumat adalah dibolehkan karena merapatkan shaf berpotensi penularan penyakit membahayakan jiwa manusia maka hukumnya haram (At Tusi Buchari, 2020). MUI memberikan ketetapan hukum terkait solat Jum'at dengan merenggangkan saf yaitu dibolehkan. Hukum merapatkan shaf kembali wajib jika pemicu menjadi haram hilang.

Problim sholat jumat yang lain dimasa pandemi covid 19 adalah sholat memakai masker. Muka adalah bukan termasuk aurat, jika ditutup dengan masker hukumnya makruh dan batal atau tidak sholat jumatnya. Sedang pemerintah mewajibkan jamaah sholat jumat pakai masker ketika sholat jumat. Hal ini menjadi problem sholat jumat di masa pandemi covid 19. Menurut ulama Nahdatul Ulama memakai masker saat sholat jumat di masa pandemi dibolehkan dengan syarat masker terebut suci, jika terkena najis maka haram hukumnya memakai masker yang terkena najis. Sedangkan ulama Muhammadiyah berpendapat, pertama jika 
seseorang shalat dengan memakai masker tanpa uzur syar'i, maka hukumnya makruh karena wajah tidak menyentuh tempat sujud, tetapi shalatnya sah. Kedua jika seseorang shalat jumat dengan memakai masker karena ada uzur syar'i maka hukumnya mubah atau boleh dan sholatnya sah. Pemakaian masker dalam sholat jumat untuk menghindari atau untuk antisipasi terpaparnya covid 19 (Sutarno, 2020). Pendapat lain adalah diperbolehkan memakai masker saat sholat jum'at jika ada uzur jika tidak ada uzur maka makruh hukumnya karena dahi dan hidung tidak tidak menyentuh tempat sujud (Safa, admin, 2021), Sedangkan Widiyani Rosmha berpendapat bahwa memakai masker ketika sholat untuk ntisipasi tertular penyakit yang berbahaya maka hukumnya mubah (Widiyani Rosmha, 2020). MUI dalam fatwanya membolehkan jamaah shalat jumat memakai masker ketika shalat Jumat selama pandemic, jika pandemi sudah berlalu maka makruh memakai masker dalam sholat jumat.

Problim sholat jumat yang lain di masa pandemi covid 19 adalah durasi khutbah jumat. Pemerintah memerintahkan jika sholat jumat diselenggarakan maka durasi nya diperpendek untuk mengurangi lama pertemuan antara jamaah satu dengan yang lainnya. Durasi khotbah dikurangi merupakan suatu problem karena berkurangnya ilmu Islam yang diserap oleh jamaah. MUI memberi fatwa bahwa Khutbah Jum'at diperpendek dan begitu juga bacaan surat sesudah al fatihah memilih surat pendek saja demi untuk pencegahan covid 19, hal ini berlaku sampai covid 19 berlalu (Co, Tempo, 2021).

Hukum shalat jumat diganti sholat dhuhur merupakan suatu problem sholat jumat di masa pandemi. Menurut Jamik Solikin shalat jumat boleh diganti dengan shalat dhuhur di rumah masing masing, hal ini didasarkan pada dasar peralihan peralihan kewajiban pengganti. Qaidah Fiqhiyah Apabila yang pokok tidak dapat dilaksanakan, maka beralihkepada pengganti (Jamik, 2020). Widiyani Rosmha berpendapat bahwa shalat jumat boleh diganti dengan sholat dhuhur selama pandemic covid 19 (Widiyani Rosmha, 2020). Penulis lain berpendapat bahwa sholat jumat boleh diganti dengan dhuhur di masa pandemic covid 19 (Aditya, 2021). MUI memberi fatwa bhwa sholat jumat pada masa pandemic diganti dengan sholat dhuhur bagi yang sedang sakit, dan bagi yang sehat jika terjadi PPKM.

Hukum shalat jumat berbilang. Shalat jumat boleh berbilang jika masjid tidak bisa memuat yang seharusnya karena diterapkan jaga jarak 1 meter antara jamaah yang satu dengan yang lain. Jika shalat jumat tidak berbilang maka shalat boleh diselenggarakan di masjid masjid yang ukuran kecil kapasitasnya, atau boleh diselenggarakan di mushola mushola (Co, Tempo, 2021). Juga munculnya perbedaan pendapat tentng boleh dan tidaknya dihentikan penyelenggaraan sholat Jum'at, dan tentang shalat jumat denga cara siff. Problim ini diberi solusi oleh MUI untuk memilih salah satu diantara dua pendapat.

Tidak diselenggarakan shalat jumat berdampak pada kehidupan sosial. Diantaranya adalah berkurangnya 1 . Pembelajaran persamaan hak, pada poin ini memberikan contoh bahwa semua manusia dihadapan Allah sama untuk menjadi 
imam sholat jumat atau menjadi khatib sholat jumat, yang membedakan ketaqwaan atau keahliannya untuk menjadi imam atau khatib sholat jumat. 2. Keadilan, poin ini memberi contoh semua orang berhak untuk mendapatkan barisan depan dalam jamaah sholat jumat dengan memenuhi syarat jamaah datang lebih awal dari yang lain dan yang datang kemudian wajib menerima tempat yang masih tersedia tidak boleh menggeser tempat orang lain. 3. Kemerdekaan, poin ini adalah tiap manusia bebas memilih apa yang diingi dalam sholat jumat, apakah jamaah ingin duduk dibarisan depan atau di tengah atau di belakang, atau menjadi imam atau khatib jika jamaah tersebut mampu, atau menjadi makmum atau jadi muadzin 4. Solidaritas, poin ini adalah jamaah merasakan apa yang dirasakan jamaah lain sehingga mendoronguntuk bersatu dalam visi dan misi 5 Simpati, poin ini adalah sejauh mana manusia merasakan apa yang dirasakan orang lain dan memberi solusi, dan 6 . Empty poin ini merasakan apa yang dirasakan orang lain tapi tidak sampai memberi solusi (Hasan Rosidin, 2020). Problim ini belum tergantikan seluruhnya, kecuali sedikit dilaksanakan pembelajaran di rumah dan lingkungan alam sekitar rumah.

Tidak diselenggarakan shalat jumat berdampak pada kehidupan ekonomi. Kurangnya jamaah sholat di masjid 1. Kerja sama di bidang ekonomi seperti mendirikan simpan pinjam tanpa bunga. 2. Perolehan shadaqah sunnah untuk pemeliharaan masjid, 3. Bermusyawarah dalam pengguanaan dana masjid, 4. Penyelenggaraan korban pada hari raya korban, 5. Shadaqah ta'jilan di bulan ramadhan, 6. Musyawarah untuk menerima dan menyalurkan zakat fithrah. Problem ini belum tergantikan diluar masjid mengingat awal mula masjid sebagai tempat untuk berbudaya Islam dalam segala aspek kehidupan termasuk di bidang ekonomi (Hasan Rosidin, 2020). Problem ini hanya sedikit bisa dialihkan kegiatan tersebut di luar masjid, atau dibawa ke lingkungan rumah.

Problem lainnya jika tidak diselenggarakan shalat jumat berdampak pada pendidikan anak. Selain anak tidak ada pembelajaran secara praktek tentang shalat jumat, mereka juga kurang bersosialisasi dengan orang lain dan teman sebaya diluar rumahnya, berkurangnya pengalaman persamaan hak, keadilan, kemerdekaan, solidaritas, simpati, empati, kurangnya motivasi belajar membaca Al Qur'an, menghafal surat al Qur'an, kurangnya motivasi untuk bias mengutarakan pendapatnya di muka umum seperti yang dilakukan oleh khatib. Problem ini tidak bisa digantikan dengan kegiatan lain tapi sedikit jika dialihkan ke kegiatan lain karena kegiatan lain hanya eksedental tidak rutin seperti ibadah shalat jumat seminggu sekali. Problem ini akan berakir jika covid 19 sudah bisa diatasi oleh manusia.

\section{Kesimpulan}

Uraian dalam pembahasan diatas dapat disimpulkan bahwa problimatika shalat jumat pada masa pandemic covid 19 ada dua problem yaitu: 1. Problim diselenggarakan shalat jumat pada masa pandemic covid 19. Problim yang muncul adalah a. Hukum memakai masker dalam shalat jumat, b. Hukum tidak meluruskan shaf dalam shalat 
jumat, c. Hukum tidak merapatkan shaf dalam shalat jumat, d. Hukum penyelenggaraan berbilang atau dengan cara sif dalam sholat jumat disebabkan masjid tidak bisa menampung jamaah shalat jumat yang seharusnya, e. Hukum penyelenggaraan shalat jumat di mushala atau di rumah, f. Hukum memperpendek khutbah jumat, g. Hukum memperpendek sholat dengan cara memilih surat pendek dari Al Qur'an. Problematika shalat jumat pada masa pandemi covid 19 di poin satu ini tidak ada solusi karena hukumnya sudah pasti, tapi hanya membutuhkan solusi sementara selama masa pandemi covid 19, hal ini sudah dilakukan oleh Majlis Ulama Islam dan problem ini berakir jika pandemi covid 19 sudah tidak melanda lagi di suatu wilayah atau seluruh wilayah Negara Kesatuan Republik Indonesia. 2. Problem tidak diselenggarakan shalat jumat. Problim yang muncul adalah a. Di bidang Aqidah yaitu kurangnya iman dan taqwa pada Allah dan peraturan-Nya terutama perintah sholat jumat; berkurangnya iman dan taqwa pada Allah dan peraturan-Nya karena berkurangnya ilmu Islam yang diperoleh dari materi khuthbah jumat yang disampaikan oleh khatib jumat; berkurangnya pembiasaan meluangkan waktu untuk silaturrahim melalui waktu shalat jumat. b. Di bidang Hukum yaitu terkait dengan hukum tidak melaksanakan shalat jumat tiga kali berurutan, c. Di bidang Sosial yaitu pembelajaran persamaan hak, keadilan, kemerdekaan, solidaritas, simpati, dan empati. d. Di bidang Ekonomi yaitu kurangnya kerjasama di bidang ekonomi seperti mendirikan simpan pinjam tanpa bunga, perolehan shadaqah sunnah untuk pemeliharaan masjid, bermusyawarah dalam pengguanaan dana masjid, penyelenggaraan korban pada hari raya korban, shadaqah ta'jilan di bulan ramadhan, musyawarah untuk menerima dan menyalurkan zakat fithrah. e. Di bidang Pendidikan yaitu selain anak tidak ada pembelajaran secara praktek tentang shalat jumat, juga mereka kurang bersosialisasi dengan orang lain dan teman sebaya diluar rumahnya, berkurangnya pengalaman persamaan hak, keadilan, kemerdekaan, solidaritas, simpati, empati, kurangnya motivasi belajar membaca Al Qur'an, menghafal surat al Qur'an, kurangnya motivasi untuk bisa mengutarakan pendapatnya di muka umum atau untuk mempresentasikan ide gagasan pada orang tuanya gurunya atau di muka umum seperti yang dilakukan oleh khatib. 


\section{BIBLIOGRAFI}

Aditya, Rifan. (2021). Hokum Ganti Sholat Jumat dengan Sholat Dhuhur Selama Pandemi Covid 19. Retrieved from jakarta: http://www.suara.com

Alsha Tour. (2017). Sholat Jumat: Pengertian, Hukum, Keutamaan, dan Sunnahnya.

Amalia Resti. (2015). Persamaan Hak Dan Kesamaan Derajat. Retrieved from retiamalia8.blogspot.com

Anggraeni, Tri Okta. (2017). Pembiasaan Shalat Dzuhur dan Shalat Jum'at dalam Pembinaan Nilai-nilai Religius Siswa di SMP Negeri 3 Jeruklegi Cilacap. IAIN.

Azizah Kurnia. (2021). 5 Keutamaan Sholat Jumat dan Dalilnya, Wajib Diketahui Umat Islam. m.merdeka.com.

Dosen Pendidikan 3. (2021). Solidaritas - PengertianMenurut Para Ahli, Jenis, Manfaat, Prinsip,Faktor, Hal, Ancaman \& Contoh. Retrieved from dosenpendidikan.co.id

Efendi, Saprin, Lubis, Saiful Akhyar, \& Nasution, Wahyudin Nur. (2018). Problematika Pembelajaran Pendidikan Agama Islam Di Sd Negeri 064025 Kecamatan Medan Tuntungan. EDU-RILIGIA: Jurnal Ilmu Pendidikan Islam Dan Keagamaan, 2(2). Google Scholar

Firdaus, Fitra. (2020). Isi Lengkap Fatwa MUI tentang Sholat Jumat Saat Pandemi Covid-19. Retrieved from jakarta: http://www.suara.com

Hasan Rosidin. (2020). Sholat dan Kesalehan Sosial. Retrieved from sumeks.co.sholatdan-keslehansosial

Hikmah, Lailatul. (2019). Problimatika Pembelajaran Fiqih MIS Muhammadiyah Sinar BantenKecamatan Talang Padang, Kabupaten Tanggamus. Retrieved from http:/repository.radenintan.ac,id

Humas Paser. (2019). Makna Kemerdekaan Sesungguhnya. 4. Retrieved from humas.paserkab.go.id

Indera. (2020). Semangat Didik Mengikuti Sholat Jumat. Retrieved from https:jakarta, kemenkumham.go.id

Jamik, Solikin. (2020). Shalat Jumat Diganti Sholat Dhuhur di Rumah Saja Dalam Kondisi Darurat Covid 19. Retrieved from pa.bojonegoro,go.id

Koesno, Dewi Aditya S. (2020). Apa saja Keutamaan Hari Jumat Bagi Umat Islam. Retrieved from https:/tirto.id

Mardatila Ani. (2021). Meninggalkan Shalat Jumat Hingga 3 Kali Beruntun Saat Covid 
Siti Muhayati, Diana Ariswanti Triningtyas, Carlos Lazaro Prawirosastro

19.

Mardatila Ani. (2021b). Simpati adalah Keikutsertaan Merasakan Perasaan Orang Lain, Ini Bedanya dengan Empati, Sumatera Utara.

Prawiro, M. (2019). Pengertian Sosial: Definisi, Unsur, dan Jenis Interaksi Sosial. Retrieved from maxmaroe.com

Rahasanta, Rifandi. (2017). Perancangan Masjid Nurul Islam Gambar Kerja SMA Trensains. Retrieved from https:/repository.its.ac,id

Sugiyono. (2017). Metode Penelitian Kuantitatif, Kualitatif, dan R\&D. Alfabeta: Bandung

Wahyuningsih, Kompyang Sri. (2021). Problematika Pembelajaran Daring Di Masa Pandemi Covid-19 Di Sma Dharma Praja Denpasar. Pangkaja: Jurnal Agama Hindu, 24(1), 107-118. Google Scholar

Widiyani Rosmha. (2020). Sholat Pakai Masker, Bagaiman Hukumnya Dalam Islam. Retrieved from news, detik.com

Widyakso Rendra. (2021). Konsep Keadilan Menurut Al Qur'an, Pengadilan Agama Purworejo. 18.

\section{Copyright holder:}

Siti Muhayati, Diana Ariswanti Triningtyas, Carlos Lazaro Prawirosastro (2022)

First publication right:

Syntax Literate: Jurnal Ilmiah Indonesia

This article is licensed under: 